\title{
PENINGKATAN MINAT DAN PRESTASI BELAJAR PKn MATERI KEBEBASAN BERORGANISASI MELALUI METODE PEMBELAJARAN DISKUSI PANEL DI KELAS V SDN PANDEAN LAMPER 04
}

\author{
Oleh : Bety Ismiwati ${ }^{1)}$ Sari Yustiana ${ }^{2)}$ \\ PGSD FKIP Universitas Islam Sultan Agung ${ }^{1,2)}$
}

\begin{abstract}
ABSTRAK
Penelitian ini bertujuan meningkatkan minat dan prestasi belajar PKn melalui metode pembelajaran Diskusi Panel di kelas V SDN Pandean Lamper 04 di kota Semarang. Penelitian ini merupakan Penelitian Tindakan Kelas, yang dilaksanakan dalam dua siklus, masing-masing siklus terdiri dari du pertemuan dan pada setiap siklus terdiri dari perencanaan, pelaksanaan, pengamatan,dan refleksi. Subjek penelitian adalah siswa kelas V SDN Pandean Lamper 04 yang berjumlah 28 siswa. Teknik pengumpulan data menggunakan tes dan non tes. Teknik tes digunakan untuk mengukur prestasi belajar siswa, dengan menggunakan soal evaluasi yang dilaksanakan diakhir siklus, sedangkan teknik non tes terdiri dari angket yang digunakan untuk mengukur minat belajar siswa dengan menggunakan lembar angket, kenudian observasi dengan menggunakan alat pengumpulan data yang berupa lembar observasi aktifitas guru dan lembar observasi ktivitas siswa. Hasil penelitian menunjukkan untuk hasil jumlah angket minat belajar siswa pada siklus 1 dengan kategori MS(minat sangat baik) memperoleh 3 siswa dengan presentase 10,7\% dengan kategori minat belajar siswa belum memenuhi indikator keberhasilan, sedangkan siklus II jumlah minat belajar siswa dengan kategori MS( minat sangat baik) memperoleh 26 siswa dengan presentase 92,8\%. Prestasi belajar siklus I rata-rata ketuntasan klasikalnya 64,29\% dan rata-rata 66,96, siklus II rata-rata keuntasan klasikalnya $89,29 \%$ dan rata-rata 85,18. Simpulan dalam penelitian ini adalah bahwa metode pembelajaran Diskusi Panel dapat menigkatkan minat dan prestasi belajar siswa dalam pembelajaran PKn pada siswa kelas V SDN Pandean Lamper 04 .
\end{abstract}

Kata Kunci :Minat dan Prestasi Belajar PKn ,Metode Diskusi Panel

\section{PENDAHULUAN}

Pendidikan merupakan proses untuk membantu manusia dalam sebagai seorang pendidik kita harus bisa mengembangkan potensi dalam dirinya sehingga mampu menghadapi setiap perubahan yang terjadi. Pendidikan mempunyai peranan yang sangat penting untuk mempersiapkan peserta didik agar dapat memperoleh kesuksesan dalam karier, kehidupan karier dan kehidupan pribadi,serta mampu berpartisipasi dalam membangun masyarakat. Tujuan dalam proses belajar mengajar berfungsi sebagai pedoman untuk keberhasilan belajar, menguasai cara atau metode dalam menyampaikan pelajaran agar siswa dapat memahami pelajaran dengan baik. Metode dan alat bantu pembelajaran berfungsi sebagai alat tranformasi pelajaran untuk mencapai tujuan yang telah dicapai, sehingga metode dan alat bantu dapat digunakan secara efektif dan efisien.

Agar siswa dapat menerima pelajaran denga baik maka pendidik harus menanamkan sikap minat terhadap siswa. Minat merupakan faktor untuk mendorong 
agar merasa tertarik terhadap suatu objek sehingga perbuatannya mengarah hal tersebut dan menimbulkan rasa perhatian dan senang, sehingga merupakan salah satu aspek psikis yang dapat mendorong manusia untuk mencapai tujuan. Seseorang yang mempunyai minat yang tinggi terhadap suatu objek, cenderung memberikan perhatian atau rasa senang untuk terus berusaha untuk melakukan sehingga apa yang diinginkan dapat tercapai. Namun sebaliknya apabila objek tersebut tidak menimbulkan rasa senang,maka orang itu tidak akan memiliki minat atas objek tersebut. Oleh karena itu, tinggi rendahnya perhatian atau rasa senang seseorang terhadap objek dipengaruhi oleh tinggi rendahnya minat seseorang tersebut, maka pada dampaknya prestasi siswa akan meningkat. Prestasi belajar merupakan tingkat menerima, menolak, dan menilai informasi-informasi yang diperoleh dalam proses belajar mengajar.

Berdasarkan hasil observasi dan wawancara dengan guru kelas V SDN PandeanLamper 04 yaitu Wahyuni Tugiarti S.Pd beliau mengatakan bahwa minat belajar siswa di kelas V masih rendah. Hal tersebut dibuktikan saat proses pembelajaran berlangsung khususnya mata pelajaran PKn, banyak siswa yang suka bermain sendiri dan sering tidak mengerjakaan PR yang berikan oleh guru dengan alasan lupa, ketinggalan dan lain sebagainya. Selain itu, ketika guru memberikan pertanyaan tentang materi yang telah disampaikan sebelumnya hanya beberapa siswa yang bisa menjawab. Kebiasaansiswa yang terlalu banyak menonton siaran televisi dan kurang terkontrol juga dapat membuat siswa menjadi malas untuk belajar dan mengerjakan tugas.Melihat kondisi tersebut baik kepala sekolah maupun guru sudah melakukan berbagai upaya untuk membuat siswa mejadi lebih baik yaitu dengan cara memberikan motivasi, bimbingan, nasehat dan lain sebagainya. Hal ini dilakukan dengan tujuan untuk meningkatkan minat dan prestasi belajar siswa.

Melihat kondisi permasalahan pada minat belajar siswa yang masih kurang, hal tersebut tentu akan berdampak pada prestasi belajar siswa yang masih tergolong rendah. Prestasi belajar yang masih rendah tidak hanya dipengaruhi oleh sikap minat belajar siswa yang kurang, akan tetapi ada juga faktor lain yang menyebabkan kondisi tersebut seperti penggunaan metode pembelajaran yang kurang efektif sehingga membuat siswa menjadi kurang aktif. Selain itu mata pelajaran hanya dianggap 
hanya berupa ceramah dan hafalan-hafalan semata menyebabkan siswa mejadi cepat bosan.

Prestasi belajar pada nilai Ulangan Tengah Semester siswa kelas V SD Negeri Pandean Lamper 04 Tahun Ajaran 2016/2017 belum sepenuhnya tuntas dari kriteria ketuntasan minimum (KKM) yang ditentukan sekolah yaitu 50. Hal ini diketahui bahwa dari 28 siswa hanya 20 siswa yang sudah tuntas dan 8 siswa masih belum tuntas.

Berdasarkan permasalahan tersebut, maka diperlukan suatu metode pembelajaran yang tepat demi meningkatkan nilai prestasi siswa dan salah satu caranya yaitu dengan metode diskusi panel. Keunggulan Didalam diskusi panel ini akan mengemukakan pandangan yang berbeda-beda dan bisa menimbulkan perdebatan,dalam perdebatan mau tidak mau siswa harus bisa menjawab pertanyaan dari teman-temannya,jadi sebelum presentasi siswa belajar secara tidak langsung antusias minat belajar siswa muncul,maka prestasi belajar siswa akan meningkat. Diskusi Panel merupakan suatu bentuk diskusi untuk mengungkapkan pendapat,gagasan atau pikiran yang di sampaikan dalam bentuk lisan dan untuk mencari solusi dalam sabuah masalah dan mendapat kesepahaman.Melalui metode pembelajaran diskusi panel ini dapat meningkatkan minat belajar. Hamdani (2011:214) mengemukakan Diskusi Panel"merupakan kerangka konseptual yang digunakan oleh pengajar untuk mengorganisasikan interaksi belajar mengajar dalam konteks pembahasan masalah kontroversial di lingkungannya".

Dalam karakteristik siswa SD usia 7 sampai 11 tahun menurut piaget termasuk dalam tahapan oprasional konkret,daya pikir mereka masih membutuhkan konkret nyata dalam kehidupan mereka sehari-hari ,dengan model ini siswa dapat memahami materi tentang kebebasan berorganisasi dalam pembelajaran PKn karena dalam kegiatan ini siswa menyatakan pendapat dan pikirannya secara lisan dengan tujuan untuk memecahkan suatu masalah bersama. Kemampuan siswa dalam menyatakan pendapat dan pikirannya untuk memecahkan masalah pada pelajaran PKn membuat suasana belajar PKn menjadi lebih hidup dan komunikatif yang kemudian dapat meningkatkan pemahaman siswa terhap dan pelajaran PKn, serta dapat meningkatkan prestasi belajar siswa menjadi lebih baik.

Dalam hal ini dikemukakan permasalahannya, dengan rumusan masalah, yaitu Apakah minat belajar siswapada mata pelajaran Pendidikan 
Kewarganegaraan materi kebebasan berorganisasi dapat ditingkatkan melalui metode pembelajaran Diskusi Panel pada siswa kelas V SD Negeri Pandean lamper 04 ?

Apakah prestasi belajar siswapada mata pelajaran Pendidikan Kewarganegaraan materi kebebasan berorganisasidapat ditingkatkan melalui metode pembelajaran Diskusi Panel pada siswa kelas V SD Negeri Pandean lamper 04 ?

\section{METODOLOGI PENELITIAN}

Penelitian dilakukan di kelas V SD Negeri Pandean Lamper 04 Kecamatan Gayamsari Kota Semarang dengan jenis penelitian tindakan kelas (PTK).Waktu penelitian dilaksanakan mulai bulan November s/d Maret 2017 pada semester genap tahun ajaran 2016/2017. Yang berjumlah 28 yang terdiri dari 13 siswa Laki-laki dan 15 siswa Perempuan. Teknik pengumpulan data dalam penelitian ini menggunakan teknik tes dan non tes. Teknik tes menggunakan soal evaluasi di setiap akhir siklus untuk mengetahui peningkatan prestasi belajar siswa . sedangkan teknik non tes yaitu berupa angket untuk mengetahui peningkatan sikap minat belajar siswa .observasi untuk mengamati proses pembelajaran berlangsung menggunakan lembar observasi aktivitas guru dan siswa,wawancara untuk mengetahui permasalahan yang ada di kelas $\mathrm{V}$ dan dokumentasi sebagai bukti nyata dalam melaksankan penelitian.

\section{HASIL DAN PEMBAHASAN}

Hasil penelitian tentang minat belajar siswa kelas V SD Negeri Pandean Lamper 04 materi kebebasan berorganisasi melalui metode

Pembelajaran Diskusi Panel mengalami peningkatan yang direkap pada tabel di bawah ini.

Tabel 1. Hasil Angket Minat Per Indikator

\begin{tabular}{cccc}
\hline No & Indikator & Siklus1 (\%) & Siklus 2 (\%) \\
\hline 1 & Perasaan senang & $72,14 \%$ & $87,50 \%$ \\
2 & Perhatian dalam Belajar & $75,48 \%$ & $88,57 \%$ \\
3 & Ketertarikan dalam materi pelajaran & $76,43 \%$ & $92,14 \%$ \\
\hline \multirow{4}{*}{ jumlah } & $74,68 \%$ & $89,40 \%$ \\
& Kategori & Baik & Sangat Baik \\
\hline
\end{tabular}


Peningkatan minat belajar siswa disajikan dalam tabel histogram di bawah ini:

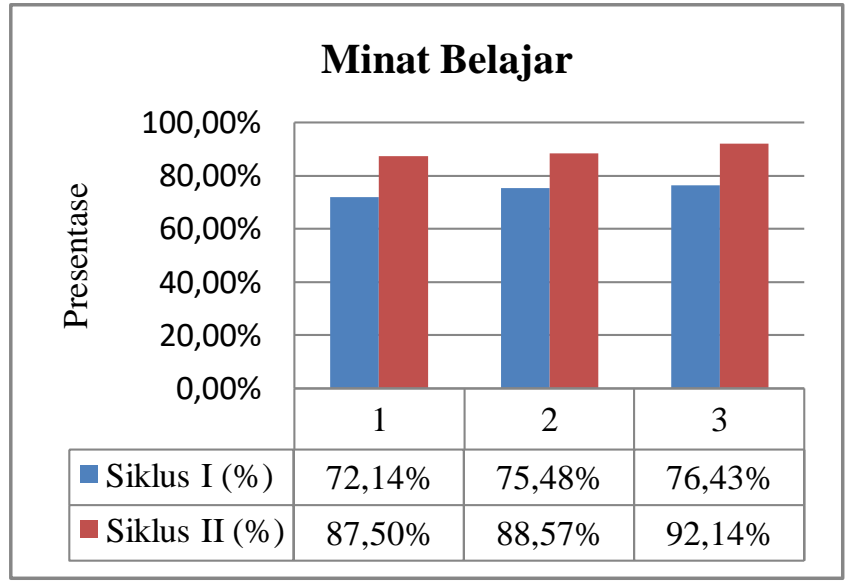

Gambar 1. Histogram peningkatan minat per indikator

Berdasarkan tabel dan diagram diatas, pada siklus II meningkat dengan jumlah terjadi peningkatan minat belajar siswa. minat belajar siswa sangat baik yang Pada siklus I jumlah minat yang dimiliki berjumlah $89,40 \%$. oleh sudah baik yang berjumlah $74,69 \%$,

Tabel 2. Rekapitulasi Jumlah Minat Siswa

\begin{tabular}{cccc}
\hline No. & Kriteria & Siklus I (\%) & $\begin{array}{c}\text { Siklus II } \\
(\%)\end{array}$ \\
\hline 1 & TM & - & - \\
2 & MK & - & - \\
3 & MC & $7,1 \%$ & - \\
4 & MB & $82,1 \%$ & $7,1 \%$ \\
5 & MS & $10,7 \%$ & $92,8 \%$ \\
\hline
\end{tabular}


Peningkatan jumlah minat siswa disajikan dalam histogram di bawah ini:

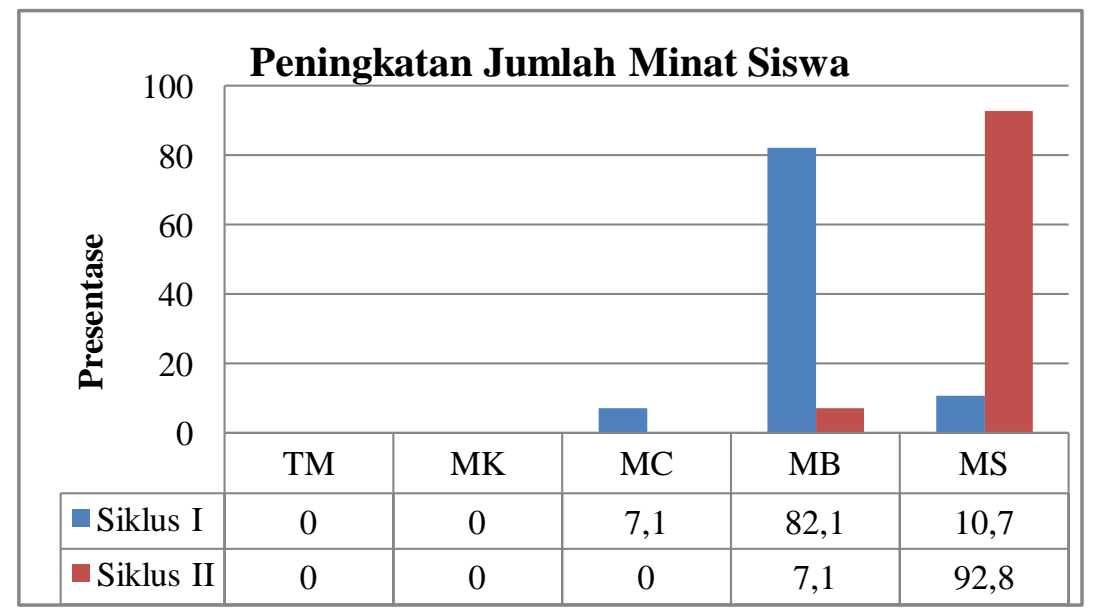

Gambar 2. Histogram jumlah minat siswa

Berdasarkan tabel da diagram jumlah minat siswa terjadi peningkatan dari siklus I dan siklus II. Pada siklus I jumlah minat siswa yang memiliki minat belajar cukup (MC) ada 2 anak dengan presentase 7,1\%, sedangkan jumlah minat siswa yang dimiliki minat belajar baik (MB) ada 23 anak dengan presentase $82,1 \%$, dan jumlah minat siswa yang memiliki minat sangat baik ada 3 anak dengan presentase 10,7\%. Pada siklus II jumlah minat siswa yang dimiliki minat baik ada 2 anak dengan presentase $7,1 \%$, dan jumlah minat siswa yang dimiliki pada minat sangat baik ada 26 anak dengan presentase $92,8 \%$.

Tabel 3. Rekapitulasi peningkatan prestasi belajar

\begin{tabular}{ccccc}
\hline No & Siklus & Rata-Rata & Tuntas & $\begin{array}{c}\text { Tidak } \\
\text { Tuntas }\end{array}$ \\
\hline 1 & I & $66,96 \%$ & $64,29 \%$ & $35,71 \%$ \\
2 & II & $85,18 \%$ & $89,29 \%$ & $10,71 \%$ \\
\hline
\end{tabular}


Peningkatan prestasi belajar dapat disajikan dalam bentuk histogram di bawah ini:

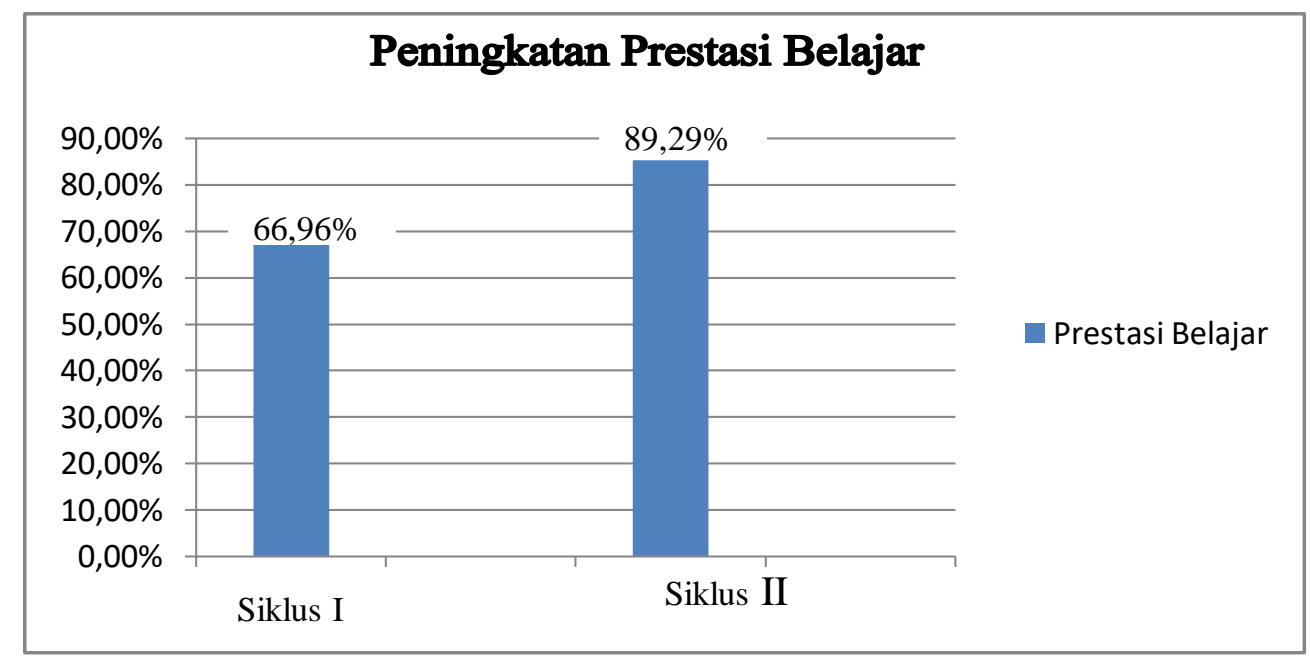

Gambar 3. Histogram peningkatan prestasi belajar

Berdasarkan tabel dan grafik diatas, diketahui nilai rat-rata pada siklus I yaitu $66,96 \%$, dengan jumlah siswa yang tuntas adalah 18 siswa mencapai $64,29 \%$. Hal ini berarti prestasi belajar masih dibawah kriteria ketuntasan klasikal. Pada siklus I diadakan refleksi untuk memperbaiki proses pembelajaran agar hasinya meningkat. Pada siklus II diperoleh nilai rata-rata yaitu $85,18 \%$ dengan jumlah siswa yang tuntas 25 siswa mencapai $89,29 \%$. Hal ini berarti prstasi siswa sudah memenuhi KKM yang telah ditetapkan yaitu mrndapatkan lebih dari nilai minimum 70 mencapai $89,29 \%$ dari jumlah keseluruan siswa kelas V.

\section{SIMPULAN}

Dari hasil penelitian di atas, dapat disimpulkan bahwa metode Diskusi Panel dapat meningkatkan minat dan prestasi belajar siswa pada mata pelajaran PKn materi kebebasan berorganisasi di kelas $\mathrm{V}$ SDN Pandean Lamper 04.

\section{SARAN}

Guru sebaiknya membimbing dan memantau siswa dalam proses pembelajaran berlangsung seperti menentukan menjadi modelator ,notulis dan panelis dalam metode diskusi panel.

\section{DAFTAR PUSTAKA}

Hamdani. (2010). Strategi Belajar Mengajar. Bandung: Pustaka Setia. 